\title{
Biodireito e suas implicações nas pesquisas em genética humana
}

\section{Biolaw and its implications on research on human genetics}

\author{
Amanda Gilvani Cordeiro Matias \\ UFBA, Vitória da Conquista, Bahia, Brasil \\ amathias.ufba@gmail.com \\ Kamilla Menezes Oliveira \\ UFBA, Vitória da Conquista, Bahia, Brasil \\ dartoflove@hotmail.com \\ Lorena Pedreira Conceição \\ UESC, Ilhéus, Bahia, Brasil \\ lorepc17@hotmail.com \\ Monaliza Oliveira Lima \\ UFBA, Vitória da Conquista, Bahia, Brasil \\ monaliza_mol@hotmail.com \\ Natália Layane Badaró Costa \\ UFBA, Vitória da Conquista, Bahia, Brasil \\ lay_badaro@hotmail.com

\section{Luckas Tarik Cordeiro Santana} \\ Faculdade Independente do Nordeste, Vitória da Conquista, Bahia, Brasil \\ tarikcordeiro@hotmail.com
}

\begin{abstract}
Resumo: Os avanços da biotecnologia oriundos do advento da genética e genômica vêm exigindo crescente esforço reflexivo e regulatório sobre aspectos éticos, bioéticos, de biossegurança e jurídicos, uma vez que a sociedade não pode debelar de regulamentações para manter um equilíbrio entre as pesquisas científicas e a dignidade da pessoa humana. O desafio está em ampliar e democratizar o espaço de debate sobre a bioética diante dos avanços ligados à terapia gênica, que consiste na introdução de genes modificados em outro organismo através da tecnologia do DNA recombinante. Estas práticas ainda requerem esclarecimentos e regulamentações, pois pesquisas desta natureza tem seus riscos inerentes, que podem violar o mais admirável princípio da Bioética e do Biodireito: a autonomia. Portanto, torna-se imprescindível o reconhecimento deste panorama -a sua complexidade e conflitos- que tange a bioética e o direito, diante das lacunas na intepretação e operacionalização da lei para resguardar o direito da pessoa humana em qualquer fase da vida.
\end{abstract}


Palavras-chave: terapia gênica, bioética, biodireito, engenharia genética, células-tronco.

Abstract: Advances in biotechnology derived from the advent of genetics and genomics, have been increasingly demanding a reflective and regulatory effort on ethical, bioethical, biosecurity and legal aspects, since society cannot put down regulations and has to maintain a balance between the scientific research and the dignity of the human person. The challenge is to broaden and democratize the discussion on bioethics in the face of the advances linked to gene therapies, consisting in the introduction of modified genes into another organism by recombinant DNA technology. These practices still require clarifications and regulations, as they have inherent risks, which may violate the most admirable principle of Bioethics and Biolaw: autonomy. Therefore, it is essential to recognize this scenario, its complexity and conflicts, regarding bioethics and law, given the gaps in the interpretation of the law and its implementation to protect the right of human beings at any stage of life

Key-words: gene therapy, bioethics, biolaw, genetic engineering, stem cells.

\section{Introdução}

A genética é o campo da ciência que analisa como as características são repassadas de uma geração para a seguinte. Os princípios que governam a herança de traços de uma geração para a outra foram descritos -e rapidamente se abafaram- há cerca de 150 anos. Próximo ao início do século XX, as leis da herança genética foram redescobertas em um evento que transformou a biologia para sempre. Mas, a importância do ácido desoxirribonucleico (DNA), como estrela principal da genética, não era devidamente entendida até a década de $50(1,2)$.

A partir da compreensão da genética seguindo dos avanços biotecnológicos, é possível realizar procedimentos que dependem de manipulação genética em diferentes áreas, como: a produção de transgênicos, a fertilização in vitro, pesquisas com células tronco embrionárias, terapia gênica, e técnicas moleculares para diagnóstico, entre outras aplicações que envolvem indiscutivelmente a ética e a bioética. Estas pesquisas genéticas apresentam resultados importantes e significativos; entretanto, também apresentam um grau de risco à pessoa humana, especialmente na ausência do rigor científico e ético. Assim, são necessárias prerrogativas da bioética e do biodireito de forma essencial para: evitar a violação desses direitos; resguardar 
a autonomia e o cuidado ao indivíduo, conforme está expresso na Resolução CNS 466 de 2012 (3); e impedir a recorrência de desmandos e direitos negados ao indivíduo, como já foram observados historicamente nesta área da pesquisa com seres humanos (4).

A bioética estuda a moralidade da conduta humana no campo das ciências da vida. Inclui a ética médica, mas vai além dos problemas clássicos da medicina, ao considerar os problemas éticos não abordados claramente pelas ciências biológicas. A bioética realiza papel relevante para a condução e solução de processos na área de saúde que envolvem o poder Judiciário. Vale destacar que os direitos e liberdades fundamentais somente coexistem em razão do direito à vida ser o primeiro direito inviolável da Constituição Federal de 1988, sendo preponderante sobre os demais direitos, e servindo como argumento da bioética confessional, a sacralidade da vida de onde emanam todos os direitos (5).

O biodireito é o ramo do direito que trata teoricamente da legislação e da jurisprudência relativas às regulamentações da conduta humana diante dos avanços da biologia, biotecnologia, biomedicina e medicina. Tem o objetivo principal de equalizar as regulamentações das práticas em biotecnologia, às reflexões oriundas da bioética e do respeito à autonomia da pessoa humana (6).

Assim, esta pesquisa tem o objetivo de traçar uma linha temporal a respeito dos principais acontecimentos e avanços da tecnologia do DNA recombinante, com ênfase na importância do biodireito como norte para estas pesquisas.

\section{Histórico da genética}

A base da Genética Moderna teve início nas pesquisas do monge austríaco Gregor Mendel (1822-1884) que propôs, a partir de seus próprios experimentos através de cruzamentos de variadas ervilhas que cultivava em seu próprio jardim do mosteiro, duas importantes leis da hereditariedade. Embora uma dessas leis demostrasse ser válida para todos os organismos diploides, foi ignorada pela comunidade científica da época e somente foi valorizada trinta e quatro anos após sua publicação $(1,2)$.

Por volta da época da morte de Mendel, em 1884, os cientistas, 
usando recursos ópticos mais avançados para estudar a arquitetura diminuta das células, cunharam o termo "cromossomo" para descrever os corpos finos e compridos existentes no núcleo celular. Entretanto, somente em 1902 alguém associaria Mendel aos cromossomos: um estudante de medicina da Universidade de Columbia, Walter Sutton $(2,7)$.

Com a redescoberta dos estudos de Mendel e os avanços científicos decorrentes de seus trabalhos, surgiu o interesse nas implicações e conflitos sociais da genética (8). Em 1883 Francis Galton, antropólogo inglês, fundador da eugenia e hereditariedade, iniciou uma verdadeira cruzada social e genética. Deu origem ao movimento eugenista que passou a ser denominada "evolução humana controlada". Seus seguidores acreditavam que tomando decisões conscientes de quem deveria ou não ter filhos, seriam capazes de impedir a reprodução das famílias pertencentes às classes inferiores, entre as quais as taxas de reprodução eram caracteristicamente maiores do que das classes médias superiores $(1,9)$.

A eugenia poderia se desdobrar de duas formas: a eugenia negativa, a qual criava instrumentos impeditivos para que pessoas portadoras de deficiências físicas e/ou mentais pudessem se procriar, com utilização, por exemplo, de métodos de esterilização; e a eugenia positiva, a qual incentivava pessoas com consideráveis condições de vida a se procriarem numa tentativa de melhorar a qualidade humana $(8,10)$.

Com a descoberta do Ácido Desoxirribonucléico (DNA), considerando o ponto central de informações sobre as características dos seres humanos, houve grandes avanços na ciência, inclusive no tratamento e cura, e melhor conhecimento de algumas doenças. Deste momento histórico até então, passamos a conviver com a evolução rápida das biociências, especialmente a medicina biogenética, a qual se pauta em critérios de ética visando a oferecer melhores condições de vida para os indivíduos, partindo, sobretudo, do mapeamento desse material genético (10). Essa descoberta estimulou a elaboração do "Projeto Genoma", que visava à elaboração de mapas físicos de alta resolução com a sequência de todo o DNA humano, de modo a criar e depositar as informações obtidas em um banco de dados como forma de aperfeiçoar as técnicas moleculares. O projeto levou ao consórcio 
de diversos laboratórios e centros de pesquisa de vários países $(9,10)$.

As principais metas do Projeto Genoma Humano foram: identificar todos os genes humanos; determinar a sequência dos cerca de 3,2 bilhões de pares de bases que compõem o genoma do Homo sapiens; armazenar a informação em bancos de dados; desenvolver ferramentas de análise dos dados; e transferir a tecnologia relacionada ao Projeto para o setor privado oportunizar um espaço de debate sobre os aspectos éticos, legais e sociais que pudessem surgir a partir do Projeto (11).

\section{Fertilização in vitro e seus aspectos éticos e jurídicos}

A fertilização in vitro é um método de reprodução assistida realizada por um conjunto de operações que visa unir artificialmente os gametas femininos e masculinos, dando origem a um ser humano, destinado, em geral, a superar a condição de infertilidade conjugal, e utilizado com sucesso desde $1978(12,13)$. Nesta técnica o espermatozoide fecunda o óvulo em laboratório, fora do corpo da mulher. A prática médica consolidada consiste na retirada de diversos óvulos para serem fecundados simultaneamente, evitando-se a necessidade de submeter a mulher a sucessivos procedimentos de estimulação da ovulação e aspiração folicular a cada tentativa de fecundação e desenvolvimento do embrião. No Brasil, a Resolução CFM 1.358 de 1992 (14), item I-6, declara que o número de embriões a serem transplantados não pode ser superior a quatro, com o intuito de não aumentar os riscos já existentes de multiparidade; também proíbe a utilização da reprodução assistida com o intuito de seleção de características genéticas, salvo se para a prevenção de doenças genéticas (12).

Considera-se, ainda, que a inseminação artificial pode ser homóloga (utiliza-se o sêmen do marido) ou heteróloga (utiliza-se o sêmen de um doador). No último caso, não há, pois, parentesco entre o doador e o concebido e, consequentemente, não há obrigação ou dever de alimentar entre esses $(13,15)$. Embriões não transferidos para o útero materno não podem se desenvolver em laboratório por mais de 14 dias, devendo ser descartados ou doados a outro casal estéril. Nesse caso, deve haver renúncia a direitos relacionados com a criança a nascer por parte dos doadores, assegurando-se o anonimato entre doadores e receptores (15). 
Os embriões que não são utilizados a fresco, são submetidos à técnica de criopreservação que suspende o desenvolvimento do embrião, mediante congelamento em nitrogênio líquido. São indivíduos humanos gerados e conservados em imobilidade biológica a temperaturas muito baixas, a menos de menos $196^{\circ} \mathrm{C}$, com preservação de sua capacidade de fertilização e desenvolvimento embrionário, permitindo, portanto, sua "vida" por prazo indefinido. Esta técnica de criobiologia apenas é considerada lícita com a finalidade de procriação; caso contrário, configura-se crime segundo a Lei de Biossegurança 11.105 de 2005 (13).

O descarte ou destruição dos embriões é um tema bastante polêmico, que causa conflitos no âmbito ético, religioso e jurídico. $\mathrm{O}$ descarte de embriões é determinado "quando o casal não permite o congelamento, não se realiza a transferência a fresco de todos eles, e ainda, algumas vezes em virtude de má-formação ou grave anomalia genética" (13). Este tema sobre os embriões excedentários é tratado no ordenamento jurídico pela Resolução CFM 1.358 de 1992, item V-2, que expressamente proíbe a destruição (por considera-la aborto), permitindo a criopreservação $(13,16)$.

Atualmente no Brasil, mediante a Lei 11.105 de 2005 (Lei Nacional de Biossegurança, LNB) (17), as pesquisas com células tronco embrionárias foram regulamentadas permitindo o uso de embriões inviáveis ou congelados há mais de três anos em clínicas de fertilização, com o consentimento dos genitores e a aprovação do comitê de ética em pesquisa (CEP) correspondente (13).

A prática de criopreservação de embriões excessivos, para o uso futuro para obtenção de gravidez, é passível de refutação bioética, no que se refere ao respeito aos embriões, pois o congelamento fere a dignidade e o desenvolvimento natural dos mesmos. Existe também um questionamento sobre o índice de sobrevivência pós descongelamento -de aproximadamente 70-80\%-, assim como sobre o caso em que os pais desistam da transferência por motivo de separação conjugal ou morte (16).

Por fim, essas questões bioéticas da técnica de reprodução assistida -como forma de geração de vida, incluindo as possíveis consequências para o nascituro - estão sob a responsabilidade compartilhada do casal e do laboratório contratado na manipulação embrionária, e envolvem: a autonomia e o direito reprodutivo dos pais; o respeito à nova vida; e a 
não maleficência para este novo ser humano, que não deve ser encarado como um meio, mas sim como um fim em si mesmo.

\section{Pesquisa com células-tronco embrionárias}

O termo célula-tronco, do inglês stem cell, refere-se a células precursoras que possuem capacidade de diferenciação e auto renovação ilimitadas, podendo dar origem a uma variedade de diferentes tipos celulares e teciduais. As células-tronco estão presentes no embrião, por isso são designadas de células-tronco embrionárias -deve-se esclarecer, porém, que também podem ser encontradas em tecidos adultos, originando células-tronco adultas $(18,19)$.

As células-tronco podem ser classificadas como totipotentes, pluripotentes e multipotentes, a depender da sua capacidade de diferenciação. As primeiras podem originar tanto um organismo totalmente funcional, como qualquer tipo celular do corpo, inclusive todo o sistema nervoso central e periférico. As segundas são capazes de originar qualquer tipo de tecido sem, no entanto, originar um organismo completo, visto que não podem gerar a placenta e outros tecidos de apoio ao feto. As terceiras estão mais diferenciadas, tendo a capacidade de originar apenas um limitado número de tipos teciduais $(20,21)$. As células-tronco embrionárias são células pluripotentes dotadas de grande plasticidade, que apresentam características essenciais, como uma ilimitada capacidade de proliferação indiferenciada in vitro, além de formar os derivados dos três folhetos embrionários, mesmo após um longo período em cultura(19).

Devido a suas características funcionais, as células-tronco embrionárias são utilizadas em diferentes pesquisas para regeneração de tecidos lesionados e outras. A pesquisa com células-tronco no Brasil é regulamentada pela LNB. O artigo $5^{\circ}$ da lei permite, com restrições, a manipulação de embriões humanos, produzidos por fertilização in vitro, para coleta de células-tronco. Para isto, devem ser atendidas as seguintes condições: embriões inviáveis; permissão dos genitores para realização da pesquisa; projetos encaminhados a comitês de ética em pesquisa para aprovação. A lei também veda a comercialização do material biológico relacionado ao artigo supramencionado e sua prática implica crime tipificado no artigo 15 da Lei 9.434 de $1997(19,22,23)$. 
Em 2005, o Procurador Geral da República ajuizou a Ação Direta de Inconstitucionalidade (ADIn) 3.510 defendendo a inconstitucionalidade do artigo $5^{\circ}$, fundamentado na tese central de que " $a$ vida humana acontece na, e a partir, da fecundação"(24). No curso do processo, houve a realização da primeira audiência pública da história desse tribunal, com a participação de especialistas, após a qual a ADIn foi julgada improcedente e o STF confirmou a constitucionalidade desse artigo. Mesmo com a contestação à Lei de Biossegurança, o Ministério da Saúde investiu $\mathrm{R} \$ 24$ milhões em pesquisas com células-tronco embrionárias no Brasil, particularmente sobre cardiopatias e terapias celulares. Os primeiros resultados foram divulgados em outubro de 2008, com a primeira linhagem brasileira produzida pela Universidade de São Paulo. O descumprimento do artigo $5^{\circ}$ da supracitada LNB implica detenção de um a três anos e multa (25).

\section{Aspectos jurídicos e bioéticos em terapia gênica}

A terapia gênica consiste no tratamento de doenças baseado na transferência de material genético, inserindo genes funcionais em células com genes defeituosos, com a finalidade de substituir ou complementar os genes causadores de doenças. Esta terapia é uma estratégia terapêutica que utiliza a técnica de transferência de material genético para modificar o genoma da célula-alvo "in vivo", permitindo a expressão do gene transferido.

Esta terapia também envolve o diagnóstico prévio; através dele, é possível que genes "defeituosos" sejam alterados ou substituídos por genes "normais", evitando que o indivíduo contraia a doença prevista. A terapia gênica tem campo terapêutico bem mais amplo, pois permite o desenvolvimento de novos tratamentos que liberam proteínas terapêuticas, como hormônios, citocinas, anticorpos, antígenos ou novas proteínas recombinantes (26). Essas possibilidades são vitais e significativas para indivíduos com uma doença que não encontram tratamento convencional efetivo, especialmente diante da esperança gerada pela ciência genética em proporcionar cura à sua doença.

A técnica, apesar de representar um notório avanço, também apresenta limitações e polêmicas éticas e jurídicas $(6,26)$, pois o seu uso pode induzir ações para uma situação de melhoramento genético, através da possibilidade de selecionar uma característica específica 
que os indivíduos provavelmente querem para si (células somáticas) ou para seus filhos (células germinais), sem envolver um tratamento de uma doença e sim um delineamento desejável $(13,27)$. Há uma grande diferença entre corrigir um defeito e melhorar uma característica estética, que se refere a possibilidade de melhoramento de conotação eugênica.

A questão ética da terapia na linha germinativa é mais polêmica que a da linha somática, uma vez que ela objetiva a correção de genes "defeituosos' e o melhoramento dos genes, com o intuito de alterar o esperma ou óvulo e, em consequência, melhorar as características da descendência $(13,28)$. Os critérios, à luz da bioética, no que se refere à terapia gênica somática são: (i) se terapia fenotípica eficaz existir, a opção pela intervenção gênica somente se dará se os custos forem menores; (ii) se a primeira existir de forma insatisfatória, a consideração bioética deve tender a favor da segunda; (iii) se a primeira não existir, por fim, a terapia gênica somática é obrigatório ético, independentemente de custos $(27,29)$

De acordo com alguns pesquisadores, ainda não há conhecimento suficiente dos efeitos da terapia gênica, ou dados mínimos seguros, a respeito dessa estratégia interventiva em células germinais -que ainda estão, por assim dizer, em sua fase embrionária-. Os riscos são inúmeros, potencializados pela possível irreversibilidade de efeitos indesejados; a análise fática, por sua vez, encontra-se prejudicada. Assim, há uma espécie de "acordo geral", um consenso mínimo prudencial, no sentido de, até um segundo momento de reavaliação, serem tais atividades clínicas rigorosamente fiscalizadas e relatadas sob uma legislação rígida que vise proteger a integralidade e dignidade da pessoa humana $(27,29)$.

A respeito, são comuns os seguintes argumentos: (i) violação da "autonomia" das gerações futuras, já que impossível seu consentimento frente às alterações; (ii) violação da dignidade humana com a instrumentalização do ser humano, agora heteronomamente determinado, também em clara afronta à identidade genética; (iii) verdadeiro ato contra a natureza; (iv) abertura à possibilidade de intervenções com escopo de melhoramento ou mesmo eugênicos; (v) questões de justiça, com a acentuação da discriminação entre os seres humanos $(30,31)$. 
A realização de ensaios clínicos de terapia gênica depende de aprovação prévia pelo Sistema CEP/CONEP -formado por CEP a nível local e administrado pela Comissão Nacional de Ética em Pesquisa (CONEP) a nível nacional-, e pela Comissão Técnica Nacional de Biossegurança (CTNBio), que devem autorizar procedimentos envolvendo pesquisas com DNA recombinante. A Lei supracitada permitiu para fins de pesquisa e terapia a utilização de células-tronco e delegou a Agência Nacional de Vigilância Sanitária (ANVISA), a determinação normativa para os procedimentos de coleta, processamento, teste, armazenamento, transporte, controle de qualidade e uso, através de suas Resoluções do Diretório Colegiado (RDC).

Apesar da RDC ANVISA 09 de 2011 (32) e das pesquisas clínicas com células-tronco realizadas no âmbito nacional serem previamente analisadas e aprovadas pelo sistema CEP/CONEP, que visa resguardar e proteger os participantes de pesquisas (7), o Brasil não possui regulamentação específica para as pesquisas clínicas ou terapias celulares, visando principalmente a fiscalização, segurança e eficácia destas práticas em humanos.

Finalmente, vale destacar que as únicas terapias celulares realizadas rotineiramente e regulamentadas no Brasil, são os transplantes de células-tronco hematopoiéticas ou transplante de medula óssea, com o sangue do cordão umbilical e placentário e o sangue periférico. Os avanços das biociências têm proporcionado benefícios para a humanidade e resulta em elevada expectativa de cura e qualidade de vida. Entretanto a bioética representa a luz que baliza as trincheiras entre o homem e o imponente império das biotecnociências.

\section{Organismos geneticamente modificados}

Segundo o artigo $3^{\circ}$, inciso $\mathrm{V}$ da $\mathrm{LNB}$, considera-se organismo geneticamente modificado (OGM) aquele cujo material genético de ADN/ARN tenha sido modificado por qualquer técnica de engenharia genética. Porém, o mesmo artigo, em seu $\S 1^{\circ}$ estabelece que não se inclui na categoria de OGM o resultante de técnicas que impliquem a introdução direta, num organismo, de material hereditário, desde que não envolvam a utilização de moléculas de ADN/ARN recombinante ou OGM, inclusive: fecundação in vitro, conjugação, transdução, transfor- 
mação, indução poliplóide ou qualquer outro processo natural $(33,34)$.

Os OGM surgiram em 1973, quando os cientistas Cohen e Boyer, que coordenavam um grupo de pesquisa em Stanford e na Universidade da Califórnia e davam o passo inicial para o mundo da transgenia, conseguiram transferir um gene de rã para uma bactéria -o primeiro experimento realizado com sucesso usando a técnica do DNA Recombinante (1)-. Da medicina, a biotecnologia passou para a agricultura, onde proliferou. Entretanto, ainda é grande a polêmica em torno dos transgênicos (33).

As multinacionais ocupam espaços cada vez maiores na mídia nacional apresentando à população supostos benefícios dos OGM, tais como o aumento da produção, a redução de seus custos e a aplicação dos avanços científicos em benefício dos homens; já os ambientalistas, sobretudo o Greenpeace, e as associações de defesa do consumidor, intensificam sua atuação na sociedade, buscando um movimento contra as autorizações da CTNBio para liberação de OGMs no meio ambiente e o consumo dos alimentos geneticamente modificados, motivados sobretudo pela incerteza que ainda impera sobre os efeitos e consequências que aparecerão com a liberação da biotecnologia (35).

A regulamentação da biotecnologia foi pela primeira vez considerada em 1970, quando solicitada moratória para aplicação desta tecnologia até que maiores estudos relacionados à Biossegurança fossem realizados, durante a conhecida Conferência de Asilomar. A partir desta época, vários regulamentos foram estabelecidos pelos diferentes países, visando o controle do uso desta tecnologia, considerando os aspectos de segurança para homem, animais e meio ambiente. Na Europa, duas Diretivas -219 e 220 de 1990- estabelecem, procedimentos para o trabalho em contenção e para liberação controlada no meio ambiente de OGMs $(36,37)$.

Devido ao que diz respeito especificamente à saúde humana, as normas e os procedimentos devem se referir não apenas às populações saudáveis expostas aos riscos, mas também àqueles que podem ser mais severamente afetados por condições diversas, como baixa imunidade, doenças pré-existentes, gravidez ou efeitos colaterais de medicamentos (inclusive antibióticos). Por esta razão, a sociedade brasileira, a partir de ampla consulta aos seus diferentes segmentos por intermédio do Congresso Nacional, elaborou, em 1995, legislação 
bastante inovadora no campo da engenharia genética - é interessante observar que as tecnologias da modificação genética e os estudos de seus impactos ainda eram recentes(36).

As normas de segurança envolvendo OGMs, a LNB, que dispõe sobre a Política Nacional de Biossegurança, oficializou a possibilidade de a engenharia genética trazer riscos. Aliás, se não fosse por isso, o inciso IV do $\S 1^{\circ}$ do art. 225 da Constituição Federal não determinaria o controle e a fiscalização por parte do Poder Público das pessoas que desenvolvem tais atividades $(37,38)$. Por isso, a recente Resolução CONAMA 305 de 2002, estabelecendo critérios para licenciamento ambiental de atividades em que ocorra o uso de OGM, representa um avanço para o esclarecimento dos requisitos que devem ser preenchidos para o exercício dessas atividades no Brasil -embora para alguns o excesso de exigências possa retardar ainda mais o desenvolvimento da biotecnologia-. Já o fundamento para a exigência de licenciamento foi criado pela Lei $\mathrm{n}^{\circ}$ 6.983/81, que instituiu a Política Nacional do Meio Ambiente (37).

Segundo o Regulamento técnico sobre rotulagem de alimentos e ingredientes alimentares que contenham ou sejam produzidos a partir de OGM, constituinte da Instrução Normativa Interministerial 01 de 2004 (33), a comprovação documental da presença ou ausência de OGM, mediante documentos fiscais que acompanham o alimento ou ingrediente alimentar em todas as etapas da cadeia produtiva, deverá atender a requisitos e procedimentos estabelecidos pelo Ministério da Agricultura, Pecuária e Abastecimento (MAPA) e pela ANVISA, no âmbito de suas competências.

\section{Transdisciplinaridade da ética, da bioética e do biodireito}

A ética é a referência aos valores expressos pela moral e estuda os conceitos envolvidos no raciocínio prático do que é correto, temporalmente, culturalmente, para que a vida e as atividades sociais sejam 
sustentáveis, toleráveis e agradáveis. O homem moral é aquele que age bem ou mal na medida em que acata ou inflige as regras do grupo; isto é extensivo às atividades em biociências desenvolvidas pelo próprio homem $(22,27)$.

A bioética é um braço da ética que indaga as questões que derivam especificamente da prática destas biociências, incluindo os problemas da natureza, das técnicas desenvolvidas, da distribuição do tratamento, da condição de autoridade do indivíduo e, dos limites das experimentações e intervenções aceitáveis. Também envolve a razoabilidade do poder exercido através da genética, genômica, nanociências e suas performances. Embora os preceitos da bioética norteiem as regras para possibilitar um melhor uso das tecnologias, essas regras não são coercitivas.

O biodireito é a parte do Direito que aborda a teoria, a legislação e a jurisprudência atinentes às normas regulamentares da conduta humana diante dos avanços da biotecnociências. Os pilares deste componente jurídico se encontram em três áreas peculiares: o Direito Civil, o Direito Constitucional e o Direito Penal, e têm o objetivo principal de garantir a proteção da dignidade do ser humano, frente às novas tecnologias da biomedicina e das biotecnológicas na sociedade contemporânea. Neste sentido, o biodireito representa a resposta do direito aos desafios advindos dos avanços científicos que desafiam a argúcia da jurisprudência, pois nem tudo aquilo que é possível tecnicamente, é ético $(4,25)$.

Neste contexto, as vias normativas da interface entre bioética e Direito são explícitas, visto que coexistem normas bioéticas que também apresentam natureza jurídica, como: a Declaração Universal sobre o Genoma Humano e Direitos Humanos; a Declaração Internacional sobre Dados Genéticos (21); e a Declaração Universal sobre Bioética e Direitos Humanos. Portanto, as atividades que envolvem seres humanos no âmbito das ciências aplicadas à vida, são interdisciplinares envolvendo a bioética e o campo jurídico, quando uma mesma norma pode ser entendida à luz desta dupla natureza visando a segurança e a integralidade do indivíduo $(7,19,22)$.

A Constituição Federativa de 1988 (39), em seu artigo $5^{\circ}$ caput, diz "todos são iguais perante a lei, sem distinção de qualquer natureza, garantindo-se aos brasileiros e aos estrangeiros residentes no 
País a inviolabilidade do direito à vida, à liberdade, à igualdade, à segurança e à propriedade [...]"; no mesmo artigo, no inciso III, diz "ninguém será submetido à tortura nem a tratamento desumano ou degradantes"; já no inciso X diz "são invioláveis a intimidade, a vida privada, a honra e a imagem das pessoas, assegurado o direito a indenização pelo dano material ou moral decorrente de sua violação".

\section{Considerações finais}

Os rápidos avanços e inovações tecnológicas, especialmente nas terapias gênicas, impõem a necessidade de romper com paradigmas disciplinares, indo rumo a perspectivas transdisciplinares no que se refere ao papel do biodireito relacionado à bioética, no intuito de resolver os problemas sociais de natureza biotecnológica. O biodireito, agindo nestas práticas, não pretende coibir os avanços, mas contribuir para que sejam desenvolvidos tendo resguardado o princípio da dignidade da pessoa humana.

Mecanismos de fiscalização -vinculados à biossegurança e à ética em pesquisa e direcionados pela atuação da CTNBio, da ANVISA e do sistema CEP/CONEP- são fundamentais para o devido cumprimento da legislação existente, servindo como norte ético para atividades que envolvem a saúde humana, especialmente no sentido de aumentar o rigor de aprovação de projetos e a fiscalização de maneira satisfatória por entes federados representados pelos ministérios e conselhos de ética em pesquisa.

A inclusão de uma série de dispositivos jurídicos que garantam a possibilidade de recursos às decisões técnicas tomadas pela CTNBio, ou pelos colegiados representativos legais, pode tornar a LNB mais efetiva e atuante, agilizando o processo de avaliação comercial dos OGM, das terapias gênicas, e dos nanoprodutos, ainda após sua comercialização -avaliando aqueles que gerem incertezas, quanto aos riscos potenciais de médio e longo prazo a saúde humana-.

Enfim, ainda são muitas as dúvidas do cidadão comum (consumidor de produtos ou participante das pesquisas) no que se refere 
a: viabilidade do procedimento, segurança, margem de riscos, conhecimento esclarecido e manifestação expressa da vontade para participar de pesquisa, e esse fato enfraquece o exercício da autonomia decisória. O biodireito deve cumprir um papel nesse ponto, resguardando a tutela integral da vida humana, e neste sentido, protegendo e promovendo a dignidade -no sentido de Habermas (27), como consciência do próprio valor e honra que deve ser intangível em qualquer fase da vida- e autonomia da pessoa humana.

\section{Referências}

1. Griffiths AJ, Miller JH, Suzuki DT, Lewontin R, Gelbart W. Introdução a genética. 7. ed. Rio de Janeiro: Guanabara Koogan; 2002.

2. Watson J, Berry A. DNA - o segredo da vida. Tradução, Carlos Afonso Malferrari. São Paulo: Companhia de letras; 2005.

3. Brasil. Resolução $n^{\circ} 466$ de 2012. Estabelece normas regulamentadoras de pesquisas envolvendo seres humanos, Ministério da Saúde, Conselho Nacional de Saúde. Diário Oficial República Federativa do Brasil, DF, 13 jun., 2013.

4. Tedesco VMA. Decisões judiciais no campo da biotecnociência: a bioética como fonte de legitimação. Rev. Bioética y Derecho 2013; 27(02): 28-37.

5. Möler LL. Bioética e direitos humanos: delineando um biodireito mínimo universal. Panóptica - Direito, Sociedade e Cultura 2013; 04(2): 72-93.

6. Namba ET. Manual de Bioética e Biodireito. São Paulo: Atlas; 2009.

7. Linden R. Terapia gênica: o que é, o que não é e o que será. Estudos Avançados 2010; 24 (70): 31-69.

8. Feitosa IB, Santana PM. Teles CBG. Genética do comportamento e o contraste ao paradigma da sociobiologia. Saber científico, Porto Velho 2011; 03(1): 112-131.

9. Santos VC. Eugenia vinculada a aspectos bioéticos: uma revisão integrativa. Rev.Saude Debate 2014; 38(103): 981-995.

10. Leão SF. Aspectos históricos constitucionais da eugenia. Revista estudos 2009; 036(01):55-73.

11. Correa MV. O admirável Projeto Genoma Humano. Rio de Janeiro; PHYSIS: Rev. Saúde Coletiva 2002; 12(2): 277-299.

12. Barbosa HH. Proteção jurídica do embrião humano. In: Casabona CMR e Queiroz JF. Biotecnologia e suas implicações ético-jurídicas; 2005. p. 248.

13. Almeida OM. Limitações à reprodução assistida: A Mercantilização da Espécie Humana Regras do Biodireito e da Bioética - A Necessidade de Legislação Específica (Tese). São Paulo: Universidade Pontifícia Católica; 2010. 
14. Brasil. Resolução CFM 1.358 de 1992. Item I-6. Adota normas éticas para utilização das técnicas de reprodução assistida. Diário Oficial República Federativa do Brasil, DF, 19 nov., 1992.

15. Fernandes SC. As técnicas de reprodução humana assistida e a necessidade de sua regulação jurídica. São Paulo: Renovar; 2005.

16. Badallotti M. Aspectos bioéticos da reprodução assistida no tratamento da infertilidade conjuga. Revista da AMRIGS, 2010; 54(4): 478-485.

17. Brasil. Lei $\mathrm{n}^{\mathrm{o}}$ 11.105, de 2005. Regulamenta os incisos II, IV e V do $\S$ $1^{\circ}$ do art. 225 da Constituição Federal, estabelece normas de segurança e mecanismos de fiscalização de atividades que envolvam organismos geneticamente modificados - OGM e seus derivados, cria o Conselho Nacional de Biossegurança - CNBS, reestrutura a Comissão Técnica Nacional de Biossegurança - CTNBio, dispõe sobre a Política Nacional de Biossegurança - PNB, revoga a Lei $n^{\circ}$ 8.974, de 5 de janeiro de 1995, e a Medida Provisória $n^{\circ}$ 2.191-9, de 23 de agosto de 2001, e os arts. $5^{\circ}$, $6^{\circ}, 7^{\circ}, 8^{\circ}, 9^{\circ}, 10$ e 16 da Lei $n^{\circ} 10.814$, de 15 de dezembro de 2003, e dá outras providências. Diário Oficial República Federativa do Brasil, DF, 28 maio, 2005.

18. Gritti A, Vescovi AL, \& Galli R. Adult neural stem cells plasticity and developmental potential. J. Physiol, Paris 2001; 96 (02): 81-93.

19. Silva BA, Anjos LCP, Nery FL, Narriman SOBR, et al. Implicações bioéticas na pesquisa com células-tronco embrionárias. Acta bioeth 2013; 19 (01): 87-95.

20. Gage F.H. Mammalian neural stem cells. Science, Washington, DC. 2001 (287):1433-1438.

21. Robey PG. Stem cells near the century mark. J. Clin. Invest. Thorofare. 2000; 105 (11):1489-1491.

22. Gomes D. Células-tronco embrionárias: implicações bioéticas e jurídicas. Bioethikos. Centro Universitário São Camilo 2007; 1(2): 78-87.

23. Brasil. Lei 9.434 de 1997. Dispõe sobre a remoção de órgãos, tecidos e partes do corpo humano para fins de transplante e tratamento e dá outras providências. Diário Oficial República Federativa do Brasil, DF, 05 fevereiro, 1997.

24. Brasil. Ação Direta de Inconstitucionalidade (ADIn) 3.510. DJe-096 Divulg 27-05-2010, Public 28-05-2010, Ement ;VOL-02403-01: PP-00134

25. Diniz D, Avelino D. Cenário internacional da pesquisa com célulastronco. Rev Saúde Pública 2009; 43(3): 541-547.

26. Dani SU. Terapia Gênica. Ciência e Desenvolvimento. Revista BioTecnologia 2001; 02 (12): 28-39.

27. Habermas J. O futuro da natureza humana: a caminho de uma eugenia liberal? 2 $2^{\text {a ed. Trad. Jannini K. São Paulo: Martins Fontes, } 2010 .}$

28. Lapa FB. Bioética e biodireito, um estudo sobre a manipulação do genoma humano (Dissertação). Santa Catarina(SC): Universidade Federal; 2002.

29. Archer L. Terapia génica germinativa: erradicar doenças hereditárias. In: 
Archer, L. et al (Orgs). Novos desafios à bioética. Porto: Porto; 2001.p. 168-71.

30. Archer L. Genetic testing and gene therapy: the scientific and ethical background. In: Doherty P, Sutton A (Ed). Man-made Man: ethical and legal issues in genetics. Dublin: Open Air; 1997. p. 29-45.

31. Loureiro JCSG. Constituição e biomedicina: contributo para uma teoria dos deveres bioconstitucionais na esfera da genética humana (Dissertação). Faculdade de Direito da Universidade de Coimbra; 2003.

32. Brasil. Resolução RDC $n^{\circ}$ 9, de 14 de março de 2011. Dispõe sobre o funcionamento dos Centros de Tecnologia Celular para fins de pesquisa clínica e terapia e dá outras providências. Ministério da Saúde, Agência Nacional de Vigilância Sanitária. Diário Oficial República Federativa do Brasil, DF 16 març., 2011.

33. Alves GS. A biotecnologia dos transgênicos: precaução é a palavra de ordem. (Dissertação). Natal: Universidade Estadual Rio grande Norte; 2004.

34. Brito VCM. Estudo comparativo entre melhoramento genético em vegetais e a produção de transgênicos. Rio de Janeiro: Fund Osvaldo Cruz 2006; 02(05): 078-085.

35. Suzuki JB. OGM: aspectos polêmicos e a nova lei de biossegurança. Jus Navigandi 2006; 10(997): 25-33.

36. Possas CA, Nepomuceno AL. Bioética nas atividades com plantas geneticamente modificadas: contribuição ao código de ética das manipulações genéticas. Parc. Estratégicas 2002; 07(16):163-171.

37. Luchesi CU. Considerações iniciais sobre a resolução do CONAMA sobre OGM's. Associação nacional de biossegurança. Rio de Janeiro 2010; 08(02).

38. Marinho $\mathrm{C}$, Minayo-Gomez C. Decisões conflitivas na liberação dos transgênicos no Brasil. São Paulo 2004; 18(3): 096-102.

39. Brasil. Constituição da República Federativa do Brasil: promulgada em 5 de outubro de 1988.

Recebido em: 25/09/2013 Aprovado em: 05/12/2013 